\title{
Pregnancy offers new insights into mechanisms of breast cancer risk and resistance
}

\author{
D Joseph Jerry ${ }^{1,2^{*}}$, Grace Makari-Judson ${ }^{3}$, Giovanna M Crisi ${ }^{4}$ and Karen A Dunphy ${ }^{1,2}$
}

\begin{abstract}
Pregnancy induces long-lasting changes in gene expression that are associated with a reduction in breast cancer risk. Although several mechanisms have been proposed to mediate the reduction in breast cancer risk among parous women, recent studies focus attention on progenitor cells as major targets. The results suggest new biomarkers that may improve risk prediction and provide endpoints for assessment of clinical responses to prophylactic therapies.
\end{abstract}

\section{Viewpoint}

An increased prevalence of breast cancer among Roman Catholic nuns in Italy was observed in the $1600 \mathrm{~s}$, providing early links between reproductive factors and breast cancer risk. Epidemiological studies in the 1970s identified pregnancy as a key factor in reducing the risk of breast cancer. This was evident in a variety of species and reproduced in rodent experiments. This is not a simple relationship, because the incidence of breast cancer is increased transiently during the period immediately after pregnancy in women [1], but the overall effect is that lifetime risk is reduced by up to $50 \%$ [2]. Furthermore, the protective mechanisms are robust, rendering the breast epithelium resistant to the carcinogenic effects of ionizing radiation [3] and alkylating agents [4].

Studies in rodents suggest four mechanisms to explain the protection afforded by pregnancy: (a) systemic changes in endocrine factors [5], (b) differentiation of the mammary epithelium- and stroma-reducing proliferative responses [5], (c) sensitization of pro-apoptotic pathways, especially those mediated by p53 [6,7], and

\footnotetext{
* Correspondence: jjerry@vasci.umass.edu

${ }^{1}$ Department of Veterinary \& Animal Sciences, Integrated Sciences Building, University of Massachusetts Amherst, 661 North Pleasant Street, Amherst, MA 01003, USA

${ }^{2}$ Pioneer Valley Life Sciences Institute, 3601 Main Street, Springfield, MA 01199, USA

Full list of author information is available at the end of the article
}

(d) restriction of the progenitor cell population [8]. Transcriptional profiling of mammary tissues revealed stable changes in parous rodents [9]. However, genomewide transcriptional profiling experiments using human breast tissues containing both epithelial and stromal components yielded variable results. Host factors such as age, obesity, and genetic diversity greatly influence gene expression patterns $[10,11]$ and may obscure changes in the pathway subset that are responsible for the protective effects of parity. Alternatively, the mechanisms in women may differ from those in mice.

A new study by Choudhury and colleagues [12] addressed this complexity by examining gene expression profiles in subsets of breast epithelium representing luminal $\left(\mathrm{CD} 24^{+}\right)$, myoepithelial $\left(\mathrm{CD} 24^{\text {low }} / \mathrm{CD} 10^{+}\right)$, and progenitor $\left(\mathrm{CD} 24^{\text {low }} / \mathrm{CD} 10^{\mathrm{low}} / \mathrm{CD} 44^{+}\right)$cells and stromal fibroblasts. Among these cell populations, parity had the greatest effect on gene expression patterns in the CD44 ${ }^{+}$ progenitors. The persistent effects of parity were paralleled by changes in DNA methylation, suggesting an epigenetic mechanism. The effect of parity was surprisingly robust given the limited number and diversity of patients (three nulliparous and three parous, the latter including both an African-American and a Caucasian). These results mirror experiments in mice in the lab of Meier-Abt and colleagues [13], who found that gene expression patterns altered most dramatically in the mammary stem cell population. This was corroborated by functional testing of the progenitor activity in vitro and by transplantation in vivo. Therefore, restriction of the progenitor cell population is a common effect of pregnancy in both mice and women.

The association between breast cancer risk and stem cells has been more difficult to demonstrate. Choudhury and colleagues [12] compared expression profiles of $\mathrm{CD} 44^{+}$progenitor cells from high-risk individuals who were carriers of mutations in breast cancer susceptibility genes BRCA1 and BRCA2 and found patterns to be most similar to nulliparous women regardless of parity. This suggests that parity is less protective in these 
individuals. However, epidemiological studies have been divided on this point, and the majority of recent studies demonstrated a reduction in risk among parous BRCA1/ 2 carriers which was similar to that of the general population [14]. The apparent discrepancy may be due to disruptions in cell lineages in the high-risk patients. Using cell sorting, Lim and colleagues [15] found that the breast stem cell population was reduced among the 10 $B R C A 1$ patients analyzed compared with the 30 normal controls. However, the progenitor population committed to the luminal epithelial lineage was increased [15]. Subsequent experiments demonstrated that the hormone receptor-negative luminal progenitors are the 'cells of origin' for breast cancers in BRCA1 patients $[15,16]$. Therefore, alterations in cell lineages in $B R C A 1 / 2$ mutation carriers may contribute to the clustering observed by Choudhury and colleagues. As parity has been suggested to engage multiple pathways, it is likely that there are compensatory pathways that confer protection even when the equilibrium of the cell lineages is disrupted.

The broader goal is to develop biomarkers that identify individuals who are at elevated risk and that guide selection of prophylactic therapies. The decrease in cells expressing nuclear p27 (encoded by CDKN2a) among parous women, especially the decrease in hormoneresponsive cells that are positive for both $\mathrm{p} 27$ and estrogen receptor-alpha $\left(\mathrm{p}^{2} 7^{+} / \mathrm{ER}^{+}\right)$, is intriguing [12]. The results suggest that quiescent 'hormone-sensing' cells are biomarkers of progenitor cell dynamics. The role of the $\mathrm{ER}^{+}$cells in sensing hormone exposures and regulating progenitor cells was also observed in mice [13]. In these studies, pregnancy reduced secretion of Wnt4, which limited the population of progenitor cells. Both decreases in Wnt signaling and increases in apoptosis were among the pathways altered significantly among $\mathrm{CD} 44^{+}$ cells from parous women [12].

These data reveal biomarkers of progenitor cell dynamics that can be applied to assess breast cancer risk and provide surrogate endpoints in trials assessing efficacy of chemopreventive therapies designed to restrain progenitor populations. Selective stimulation of the hormone-sensing cells to restrict Wnt expression or enhance expression of Wnt antagonists, such as secreted frizzled-related proteins, offers novel targets for chemoprevention.

\section{Abbreviation \\ ER: Estrogen receptor.}

\section{Competing interests}

The authors declare that they have no competing interests.

\section{Authors' contributions}

DJJ and KAD provided content related to the overall effects of parity. GM-J provided clinical perspectives especially related to the effects of pregnancy in BRCA1/2 patients. GMC evaluated the histopathology and potential for clinical impact. Funding related to this topic was provided by the National Cancer Institute (R01ES015739 to DJJ) and the Avon Foundation (02-2009-
011 and 02-2011-028 to DJJ, GM-J, and GMC). All authors read and approved the final manuscript.

\section{Author details}

'Department of Veterinary \& Animal Sciences, Integrated Sciences Building, University of Massachusetts Amherst, 661 North Pleasant Street, Amherst, MA 01003, USA. ${ }^{2}$ Pioneer Valley Life Sciences Institute, 3601 Main Street, Springfield, MA 01199, USA. ${ }^{3}$ Department of Hematology and Oncology, Baystate Medical Center, 3350 Main Street, Springfield, MA 01199, USA. ${ }^{4}$ Department of Pathology, Baystate Medical Center, 759 Main Street, Springfield, MA 01199, USA.

Published: 24 Sep 2013

\section{References}

1. Schedin P: Pregnancy-associated breast cancer and metastasis. Nat Rev Cancer 2006, 6:281-291.

2. Albrektsen G, Heuch I, Hansen S, Kvale G: Breast cancer risk by age at birth, time since birth and time intervals between births: exploring interaction effects. Br J Cancer 2005, 92:167-175.

3. Ronckers CM, Erdmann CA, Land CE: Radiation and breast cancer: a review of current evidence. Breast Cancer Res 2005, 7:21-32.

4. Russo $\mathrm{H}$, Russo J: Developmental stage of the rat mammary gland as determinant of its susceptibility to 7,12-dimethylbenz[a]anthracene. J Natl Cancer Inst 1978, 61:1439-1449.

5. Russo IH, Russo J: Physiological bases of breast cancer prevention. Eur J Cancer Prevention 1993, 2:101-111.

6. Jerry DJ, Kittrell FS, Kuperwasser C, Laucirica R, Dickinson ES, Bonilla PJ, Butel $J S$, Medina D: A mammary-specific model demonstrates the role of the p53 tumor suppressor gene in tumor development. Oncogene 2000, 19:1052-1058.

7. Medina D, Kittrell FS: p53 function is required for hormone-mediated protection of mouse mammary tumorigenesis. Cancer Res 2003, 63:61406143.

8. Siwko SK, Dong J, Lewis MT, Liu H, Hilsenbeck SG, Li Y: Evidence that an early pregnancy causes a persistent decrease in the number of functional mammary epithelial stem cells - implications for pregnancyinduced protection against breast cancer. Stem Cells 2008, 26:3205-3209.

9. Blakely CM, Stoddard AJ, Belka GK, Dugan KD, Notarfrancesco KL, Moody SE, D'Cruz CM, Chodosh LA: Hormone-induced protection against mammary tumorigenesis is conserved in multiple rat strains and identifies a core gene expression signature induced by pregnancy. Cancer Res 2006, 66:6421-6431

10. Pirone JR, D'arcy M, Stewart DA, Hines WC, Johnson M, Gould MN, Paul Y, Jerry DJ, Schneider SS, Troester MA: Age-associated gene expression in normal breast tissue mirrors qualitative age-at-incidence patterns for breast cancer. Cancer Epidemiol Biomarkers Prev 2012, 21:1735-1744.

11. Sun X, Casbas-Hernandez P, Bigelow C, Makowski L, Jerry DJ, Schneider SS, Troester MA: Normal breast tissue of obese women is enriched for macrophage markers and macrophage-associated gene expression. Breast Cancer Res Treat 2012, 131:1003-1012.

12. Choudhury S, Almendro V, Merino VF, Wu Z, Maruyama R, Su Y, Martins FC, Fackler MJ, Bessarabova M, Kowalczyk A, Conway T, Beresford-Smith B, Macintyre G, Cheng YK, Lopez-Bujanda Z, Kaspi A, Hu R, Robens J, Nikolskaya T, Haakensen VD, Schnitt SJ, Argani P, Ethington G, Panos L, Grant M, Clark J, Herlihy W, Lin SJ, Chew G, Thompson EW, et al: Molecular profiling of human mammary gland links breast cancer risk to a p27(+) cell population with progenitor characteristics. Cell Stem Cell 2013, 13:117-130

13. Meier-Abt F, Milani E, Roloff T, Brinkhaus H, Duss S, Meyer DS, Klebba I, Balwierz PJ, van Nimwegen E, Bentires-Alj M: Parity induces differentiation and reduces Wnt/Notch signaling ratio and proliferation potential of basal stem/progenitor cells isolated from mouse mammary epithelium. Breast Cancer Res 2013, 15:R36.

14. Milne RL, Osorio A, Ramón y Cajal T, Baiget M, Lasa A, Diaz-Rubio E, de la Hoya M, Caldés T, Teulé A, Lázaro C, Blanco I, Balmaña J, Sánchez-Ollé G, Vega A, Blanco A, Chirivella I, Esteban Cardeñosa E, Durán M, Velasco E, Martínez de Dueñas E, Tejada MI, Miramar MD, Calvo MT, Guillén-Ponce C, Salazar R, San Román C, Urioste M, Benítez J: Parity and the risk of breast 
and ovarian cancer in BRCA1 and BRCA2 mutation carriers. Breast Cancer Res Treat 2010, 119:221-232.

15. Lim E, Vaillant F, Wu D, Forrest NC, Pal B, Hart AH, Asselin-Labat ML, Gyorki DE, Ward T, Partanen A, Feleppa F, Huschtscha LI, Thorne HJ, KConFab, Fox SB, Yan M, French JD, Brown MA, Smyth GK, Visvader JE, Lindeman GJ: Aberrant luminal progenitors as the candidate target population for basal tumor development in BRCA1 mutation carriers. Nat Med 2009, 15:907-913.

16. Molyneux G, Geyer FC, Magnay FA, McCarthy A, Kendrick H, Natrajan R, Mackay A, Grigoriadis A, Tutt A, Ashworth A, Reis-Filho JS, Smalley MJ: BRCA1 basal-like breast cancers originate from luminal epithelial progenitors and not from basal stem cells. Cell Stem Cell 2010, 7:403-417.

\section{$10.1186 / \mathrm{bcr} 3482$}

Cite this article as: Jerry et al:: Pregnancy offers new insights into mechanisms of breast cancer risk and resistance. Breast Cancer Research 2013, 15:312 